Для цитирования: Хамди О., Аталла Х., Рос М.Х., Метвалли И.Х. Влияние ожирения на онкологические и хирургические результаты лечения саркомы мягких тканей бедра. Сибирский онкологический журнал. 2022; 21 (1): 91-98. - doi: 10.21294/1814-4861-2022-21-1-91-98

For citation: Hamdy O., Atallah Kh., Ros M.H., Metwally I.H.. Impact of obesity on the oncological and surgical outcomes of thigh soft tissue sarcoma. Siberian Journal of Oncology. 2022; 21(1): 91-98. - doi: 10.21294/1814-4861-2022-21-1-91-98

\title{
IMPACT OF OBESITY ON THE ONCOLOGICAL AND SURGICAL OUTCOMES OF THIGH SOFT TISSUE SARCOMA
}

\author{
O. Hamdy', Kh. Atallah¹, M.H. Ros², I.H. Metwally \\ Surgical Oncology Unit, Oncology Center Mansoura University (OCMU), Mansoura, Egypt. \\ E-mail; omarhamdy87@gmail.com¹ \\ Mansoura University Hospitals, Mansoura, Egypt ${ }^{2}$
}

\section{Abstract}

Background. Malignant soft tissue tumors are a heterogeneous group with variable prognosis and with a tendency to recurrence and distant spread, mainly to the lungs. Also, obesity is a known risk factor for many diseases and cancers and is currently a global problem. While the thigh is one of the main fat deposition areas, it is one of the commonest sites for the incidence of soft tissue sarcoma. We tried to illustrate the impact of obesity on the outcomes of thigh soft tissue sarcoma patients. Material and Methods. We retrospectively recruited data of extremity sarcomas treated at our hospital from January 2008 to January 2020. The epidemiological and clinical data of all the included patients was analyzed, then the surgical and oncological outcomes between obese and non-obese patients were compared (defining obesity as BMI more than 30). We hypothesized that fat deposition in the thigh in obese patients may delay the diagnosis of soft tissue sarcoma, lead to the discovery of the masses at a larger size and stage, and hence may affect the disease-free survival and the overall survival. Results. Obese patients had significantly larger size tumors (median: $14.7 \mathrm{vs} 9.9 \mathrm{~cm}$ ) and as such significantly higher T stage. Another significant finding was that the mean diameter of liposarcoma tumours was $15.1 \mathrm{~cm}$, while that of non-liposarcomas was $11.3 \mathrm{~cm}$ ( $p$-value=0.023). Also, although they did not have a higher prevalence of distant metastasis at initial diagnosis, their metastasis tends to be isolated in the lung. Postoperative complications occurred more frequently in obese patients in comparison to nonobese patients ( $p$-value $=0.025$ ). Neither overall nor disease-free survivals were different among both groups, although obese patients tend to have shorter DFS. Conclusion. Obesity added complexity to the diagnosis and treatment of extremity sarcoma, but seems not to affect survival.

Key words: soft tissue tumours, extremity tumours, obesity, survival.

\section{ВЛИЯНИЕ ОЖИРЕНИЯ НА ОНКОЛОГИЧЕСКИЕ И ХИРУРГИЧЕСКИЕ РЕЗУЛЬТАТЫ ЛЕЧЕНИЯ САРКОМЫ МЯГКИХ ТКАНЕЙ БЕДРА}

\author{
О. Хамди', Х. Аталла', М.Х. Рос², И.Х. Метвалли' \\ Отделение хирургической онкологии, онкологический центр Университета Мансуры, \\ Мансура, Египет. E-mail; omarhamdy87@gmail.com¹ \\ Университетские больницы Мансуры, Мансура, Египет²
}

Аннотация

Актуальность. Злокачественные опухоли мягких тканей являются гетерогенной группой опухолей с разичным прогнозом и тенденцией к частому рецидивированию и отдаленному метастазированию, преимущественно в легкие. Ожирение представляет собой глобальную проблему, являясь известным фактором риска многих заболеваний, в том числе злокачественных новооборазований. Хотя бедро представляет собой одну из основных областей отложения жира, оно является одним из наиболее 


\begin{abstract}
частых зон возникновения саркомы мягких тканей. Мы проанализировали влияние ожирения на исходы лечения у пациентов с саркомой мягких тканей (CMT) бедра. Материал и методы. Представлен ретроспективный анализ результатов лечения больных с саркомами конечностей за период с января 2008 г. по январь 2020 г. Изучены эпидемиологические и клинические данные, а также хирургические и онкологические результаты лечения больных СМТ бедра с ожирением (ИМТ более 30) и без него. Мы предположили, что отложение жира в области бедра у пациентов с ожирением может затруднить диагностику СМТ и привести к выявлению опухолей большего размера и стадии, что может повлиять на безрецидивную выживаемость и общую выживаемость. Результаты. Пациенты с ожирением имели опухоли значимо большего размера (медиана - 14,7 против 9,9 см) и более высокую стадию Т. Средний диаметр новообразований при липосаркомах составлял $15,1 \mathrm{~cm}$, при опухолях иного гистотипа - 11,3 см ( $p=0,023)$. Чаще всего наблюдались отдаленные метастазы в легких, однако их частота в сравниваемых группах значимо не различалась. Послеоперационные осложнения чаще возникали у пациентов с ожирением ( $p=0,025)$. Общая и безрецидивная выживаемость (БРВ) не отличались между группами, хотя пациенты с ожирением, как правило, имеют меньшую БРВ. Заключение. Ожирение усложняло диагностику и лечение сарком конечностей, но, по-видимому, оно не оказывало влияиния на показатели выживаемости.
\end{abstract}

Ключевые слова: опухоли мягких тканей, опухоли конечностей, ожирение, отдаленная выживаемость.

\section{Introduction}

Soft tissue sarcomas (STS) are rare neoplasms of mesenchymal origin that can occur at any anatomical site, but the most common sites are the extremities. STS are highly aggressive with a high risk of developing distant metastasis, and their management should be carried out on a multidisciplinary basis in specialized centers. The best management scenario includes wide local excision of the primary with maximal functional preservation of the limb, in addition to perioperative radiotherapy and/or chemotherapy in indicated cases [1-3]. Early diagnosis of extremity STS is crucial for the success of the treatment plan [4].

Meanwhile, obesity is an expanding epidemic that has a negative impact on cancer patients leading to increased incidence of some cancers and poorer treatment outcomes. While the thigh is one of the main fat deposition areas, it is one of the commonest sites for the incidence of soft tissue sarcoma $[5,6]$.

We hypothesized that fat deposition in the thigh in obese patients may delay the diagnosis of soft tissue sarcoma, lead to the discovery of the masses at a larger size and stage, and hence may affect the disease-free survival and the overall survival.

\section{Material and Methods}

This is a retrospective study, where the institutional registry at our Center, was thoroughly revised for thigh soft tissue sarcoma cases that attended the hospital from January 2008 to January 2020.

The inclusion criteria were 1) Pathological proven soft tissue sarcoma. 2) The thigh was the primary site. 3) BMI was recorded. Patients were excluded if pathology is uncertain or insufficient data were found on the registration system.

We analyzed the epidemiological and clinical data of all the included patients, then we compared the surgical and oncological outcomes between obese and non-obese patients (defining obesity as BMI more than 30)
The data of these patients were analyzed using SPSS version 22 (Inc, Chicago, IL). Continuous variables are presented as mean and standard deviation. Categorical variables are presented as proportions. Categorical variables among both groups were compared using the chi-square test and Fischer's exact test if sum less than 5; however, continuous parametric variables were compared using an independent student t-test. Survival analysis was done using a Kaplan Meier curve and significance determined by a log-rank test. $\mathrm{P}$-value $<0,05$ was considered significant.

We conducted this study in compliance with the principles of the Declaration of Helsinki.

\section{Results}

Out of the total number of sarcoma patients treated in our center (more than 330), the study included 41 patients diagnosed with thigh sarcoma. Females were dominating (24: 17). The mean age at diagnosis was 47.7 years, while the mean BMI was 32.1 . The most common pathological subtype was liposarcoma followed by synovial sarcoma.

Eleven patients were initially treated by systemic therapy. Bearing in mind that 8 of them were metastatic as such receiving on palliative bases, the neoadjuvant therapy was infrequently used (3 patients only). Moreover, the therapy used was dominantly chemotherapy only, except in 1 patient where combined chemoradiotherapy was given.

All operated cases even those with clinically positive nodes turned node negative in the final paraffin sections.

After a median follow-up for 13 months (0-47), recurrence was infrequent ( 3 cases) and all recurrences were combined local and distant, affecting the lungs in all cases, in addition to non-regional nodes in 2 cases. The clinical and pathological data of the included patients were summarized in Table 1.

The body mass index showed a linear correlation to the tumor size (Pearson correlation coefficient $=0.691$, 


\section{The clinical and pathological data of the included patients Клинические и патологические данные пациентов}

\begin{tabular}{|c|c|c|}
\hline \multicolumn{2}{|r|}{ Parameter/Параметр } & Value/Значение \\
\hline \multicolumn{2}{|r|}{ Age, years/Возраст, лет } & $47,7 \pm 19,1$ \\
\hline \multicolumn{2}{|r|}{ ВМI/Индекс массы тела } & $32,1 \pm 8,0$ \\
\hline \multirow{2}{*}{ Gender/Пол } & Male/Мужской & $17(41,5 \%)$ \\
\hline & Female/Женский & $24(58,5 \%)$ \\
\hline \multirow{9}{*}{$\begin{array}{c}\text { Histopathologic type/ } \\
\text { Гистотип }\end{array}$} & Liposarcoma/Липосаркома & $15(36,6 \%)$ \\
\hline & Synovial sarcoma/Синовиальная саркома & $11(26,8 \%)$ \\
\hline & Pleomorphic sarcoma/Плеоморфная саркома & $4(9,8 \%)$ \\
\hline & Leiomyosarcoma/Лейомиосаркома & $4(9,8 \%)$ \\
\hline & Rhabdomyosarcoma/Рабдомиосаркома & $2(4,9 \%)$ \\
\hline & Spindle cell sarcoma/Веретеноклеточная саркома & $2(4,9 \%)$ \\
\hline & Epithelioid sarcoma/ Эпителиоидная саркома & $1(2,4 \%)$ \\
\hline & $\begin{array}{c}\text { Malignant peripheral nerve sheath/ } \\
\text { Злокачественная опухоль оболочек периферического } \\
\text { нерва }\end{array}$ & $1(2,4 \%)$ \\
\hline & $\begin{array}{c}\text { Peripheral neuroectodermal tumour/ } \\
\text { Периферическая нейроэктодермальная опухоль }\end{array}$ & $1(2,4 \%)$ \\
\hline \multirow{4}{*}{ T stage/Т стадия } & $\mathrm{T} 1$ & $2(4,9 \%)$ \\
\hline & $\mathrm{T} 2$ & $14(34,1 \%)$ \\
\hline & $\mathrm{T} 3$ & $13(31,7 \%)$ \\
\hline & $\mathrm{T} 4$ & $12(29,3 \%)$ \\
\hline \multirow{2}{*}{$\begin{array}{l}\text { Clinical N stage/ } \\
\text { Клиническая N стадия }\end{array}$} & No & $33(80,5 \%)$ \\
\hline & N1 & $8(19,5 \%)$ \\
\hline \multicolumn{2}{|r|}{ Pathologic N stage/ypN стадия } & $\begin{array}{l}\text { All operated were node-negative/ } \\
\text { Все оперированные N-негативны }\end{array}$ \\
\hline \multirow{6}{*}{$\begin{array}{l}\text { M stage/ } \\
\text { М стадия }\end{array}$} & M0 & $33(80,5 \%)$ \\
\hline & M1 & $8(19,5 \%)$ \\
\hline & Isolated lung metastasis/Метастазы в легкие & $4(50,0 \%)^{*}$ \\
\hline & $\begin{array}{l}\text { Lung \& non-regional nodes/ } \\
\text { Метастазы в легкие и нерегионарные лимфоузлы }\end{array}$ & $2(25,0 \%)^{*}$ \\
\hline & Lung \& liver metastasis/Метастазы в легкие и печень & $1(12,5 \%)^{*}$ \\
\hline & $\begin{array}{c}\text { Lung \& brain metastasis/ } \\
\text { Метастазы в легкие и головной мозг }\end{array}$ & $1(12,5 \%)^{*}$ \\
\hline \multirow{4}{*}{$\begin{array}{c}\text { Primary therapy/ } \\
\text { Предоперационная терапия }\end{array}$} & No/Heт & $30(73,2 \%)$ \\
\hline & Yes/Да & $11(26,8 \%)$ \\
\hline & Chemotherapy alone/Химиотерапия & $10(90,9 \%)^{*}$ \\
\hline & Chemoradiotherapy/Химиолучевая терапия & $1(9,1 \%)^{*}$ \\
\hline \multirow{4}{*}{$\begin{array}{l}\text { Surgery/ } \\
\text { Операция }\end{array}$} & $\mathrm{No} / \mathrm{HeT}$ & $8(19,5 \%)$ \\
\hline & WLE & $29(70,7 \%)$ \\
\hline & WLE \& lymph node dissection/WLE и лимфодиссекция & $3(7,3 \%)$ \\
\hline & Above-knee amputation/Ампутация выше колена & $1(2,4 \%)$ \\
\hline \multirow{2}{*}{$\begin{array}{l}\text { Complications**/ } \\
\text { Осложнения** }\end{array}$} & $\mathrm{No} / \mathrm{HeT}$ & $15(36,6 \%)$ \\
\hline & Yes/Да & $14(34,1 \%)$ \\
\hline \multirow{4}{*}{$\begin{array}{c}\text { Adjuvant therapy/ } \\
\text { Адъювантная терапия }\end{array}$} & $\mathrm{No} / \mathrm{HeT}$ & $7(17,1 \%)$ \\
\hline & Yes/Да & $26(63,4 \%)$ \\
\hline & Radiotherapy/Лучевая терапия & $18(69,2 \%)^{*}$ \\
\hline & Chemoradiotherapy/Химиолучевая терапия & $8(30,8 \%)^{*}$ \\
\hline \multirow{2}{*}{$\begin{array}{l}\text { Recurrence in operated } \\
\text { patients/ } \\
\text { Рецидивы после операций }\end{array}$} & $\mathrm{No} / \mathrm{HeT}$ & $28(63,3 \%)$ \\
\hline & Yes/Да & $3(7,3 \%)$ \\
\hline
\end{tabular}

Notes: * - valid percent; $* *$ - available registered data.

Примечания: * - допустимый процент; ** - доступные зарегистрированные данные. 


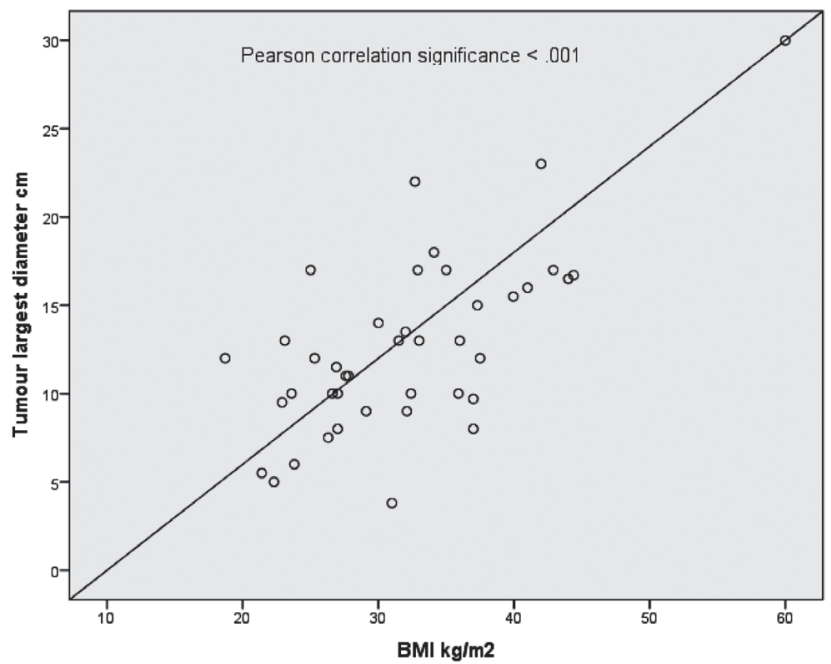

Fig.1. Scatter graph showing the correlation between BMI and tumor size

Рис. 1. Диаграмма рассеяния, показывающая корреляцию между ИМТ и размером опухоли

p-value $<0.001$ ) (fig. 1). Obese patients had significantly larger size tumors (mean $14.7 v s 9.9 \mathrm{~cm}$, p-value $=0.002$ ) and as such significantly higher $\mathrm{T}$ stage (11 patients diagnosed with $\mathrm{T} 4$ tumors vs only one patient in the non-obese group) according to AJCC $8^{\text {th }}$ edition ( $\mathrm{p}$-value $=0.035)$. Also, although they did not have a higher prevalence of distant metastasis at initial diagnosis, their metastasis tends to be isolated in the lung. Another significant finding was that the mean diameter of liposarcoma tumours was $15.1 \mathrm{~cm}$, while that of non-liposarcomas was $11.3 \mathrm{~cm}$ ( $\mathrm{p}$-value $=0.023$ ).

In addition, postoperative complications occurred more frequently in obese patients in comparison to non-obese patients ( $\mathrm{p}$-value $=0.025$ ). The commonest complication in obese patients was wound dehiscence followed by seroma. Complications were mostly Clavien-Dindo (CD) 3 and 4, however; there was no significant difference either in type or CD grade of complications between the two groups. Neither overall nor disease-free survivals were different among both groups, although obese patients tend to have shorter DFS (fig. 2, 3). The comparison between the group of obese and non-obese patients is summarized in Table 2 .

\section{Discussion}

Soft tissue sarcoma is a rare category of neoplasms that accounts for about $1 \%$ of adult malignant tumors. It occurs mainly in the extremities, trunk, and retroperitoneum. STS family includes many pathological subtypes exhibiting various clinical presentations and necessitating different approaches for management putting into consideration the molecular and histological characteristics, clinical presentation, staging, and other patient-related factors. Management

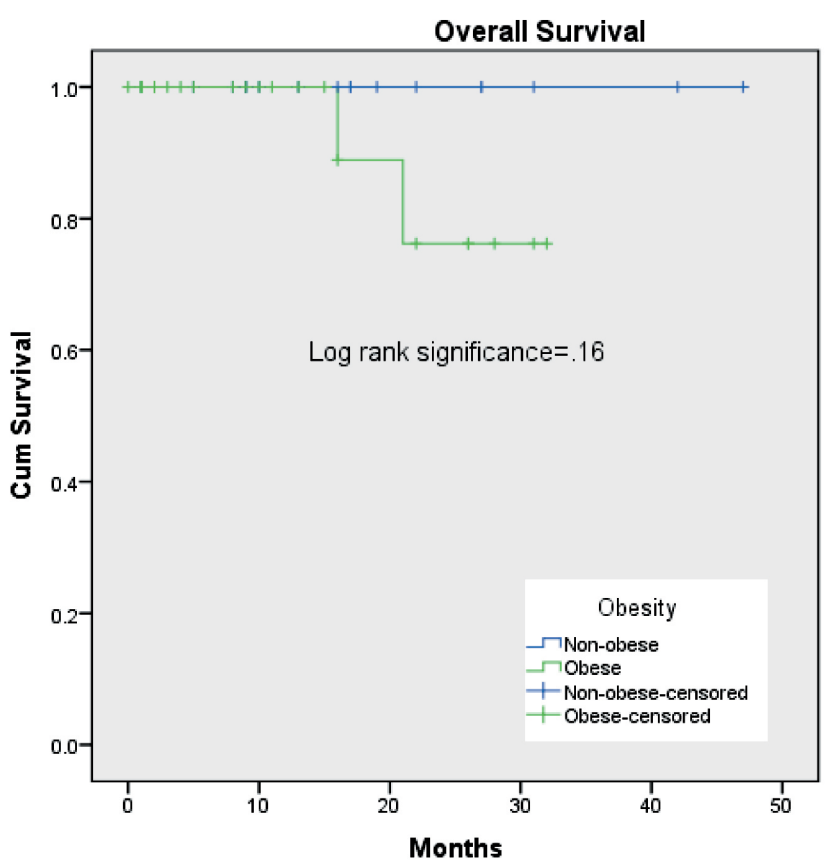

Fig. 2. Kaplan-Meier curve comparing overall survival between obese and non-obese patients

Рис. 2. Кривая Каплана-Мейера, сравнивающая общую выживаемость между пациентами с ожирением и без него

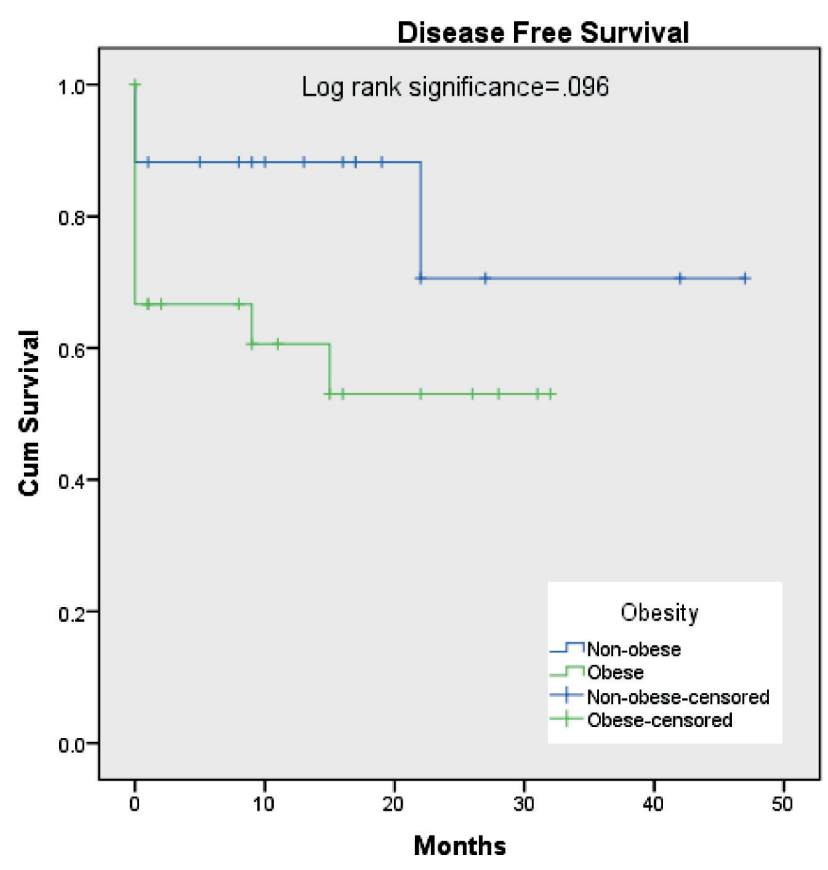

Fig. 3. Kaplan-Meier curve comparing disease-free survival between obese and non-obese patients

Рис. 3. Кривая Каплана-Мейера, сравнивающая безрецидивную выживаемость между пациентами с ожирением и без него 
The comparison between the group of obese and non-obese patients Сравнение между группами пациентов с ожирением и без ожирения

\begin{tabular}{|c|c|c|c|c|}
\hline \multicolumn{2}{|r|}{ Parameter/Параметр } & $\begin{array}{l}\text { Obese/Ожирение } \\
(\mathrm{n}=24)\end{array}$ & $\begin{array}{l}\text { Control/Контроль } \\
(\mathrm{n}=17)\end{array}$ & $\begin{array}{l}\text { Significance/ } \\
\text { Значимость }\end{array}$ \\
\hline \multicolumn{2}{|c|}{ Age mean, years/Средний возраст, лет } & $52,0 \pm 16,5$ & $41,6 \pm 21,3$ & 0,086 \\
\hline \multirow{2}{*}{ Gender/Пол } & Male/Мужской & $7(29,2 \%)$ & $10(58,8 \%)$ & \multirow{2}{*}{0,12} \\
\hline & Female/Женский & $17(70,8 \%)$ & $7(41,2 \%)$ & \\
\hline \multirow{2}{*}{$\begin{array}{c}\text { Histopathologic type/ } \\
\text { Гистотип }\end{array}$} & Liposarcoma/ Липосаркома & $11(45,8 \%)$ & $4(23,5 \%)$ & \multirow{2}{*}{0,19} \\
\hline & Others/Другие & $13(54,2 \%)$ & $13(76,5 \%)$ & \\
\hline \multicolumn{2}{|c|}{ Tumour size mean, cms/Средний размер опухоли, см } & $14,7 \pm 5,4$ & $9,9 \pm 3,0$ & 0,002 \\
\hline \multirow{4}{*}{$\begin{array}{l}\text { T stage/ } \\
\text { Т стадия }\end{array}$} & $\mathrm{T} 1$ & $1(4,1 \%)$ & $1(5,9 \%)$ & \multirow{4}{*}{0,035} \\
\hline & $\mathrm{T} 2$ & $5(20,8 \%)$ & $9(52,9 \%)$ & \\
\hline & T3 & $7(29,2 \%)$ & $6(35,3 \%)$ & \\
\hline & $\mathrm{T} 4$ & $11(45,8 \%)$ & $1(5,9 \%)$ & \\
\hline \multirow{2}{*}{ N стадия } & No & $18(75 \%)$ & $15(88,2 \%)$ & \multirow{2}{*}{0,43} \\
\hline & N1 & $6(25 \%)$ & $2(11,8 \%)$ & \\
\hline \multirow{6}{*}{$\begin{array}{l}\text { M stage/ } \\
\text { М стадия }\end{array}$} & M0 & $18(75,0 \%)$ & $15(88,2 \%)$ & \multirow{2}{*}{0,43} \\
\hline & M1 & $6(25 \%)$ & $2(11,8 \%)$ & \\
\hline & Lung metastasis/Метастазы в легкие & $4(66,7 \%)$ & - & \multirow{4}{*}{0,46} \\
\hline & $\begin{array}{c}\text { Lung \& non-regional nodes/Метастазы в легкие } \\
\text { и нерегионарные лимфоузлы }\end{array}$ & $2(33,3 \%)$ & - & \\
\hline & $\begin{array}{c}\text { Lung \& liver metastasis/ } \\
\text { Метастазы в легкие и печень }\end{array}$ & - & $1(50,0 \%)$ & \\
\hline & $\begin{array}{l}\text { Lung \& brain metastasis/ } \\
\text { Метастазы в легкие и головной мозг }\end{array}$ & - & $1(50,0 \%)$ & \\
\hline \multirow{2}{*}{$\begin{array}{c}\text { Primary therapy/ } \\
\text { Предоперационная } \\
\text { терапия }\end{array}$} & $\mathrm{No} / \mathrm{HeT}$ & $15(62,5 \%)$ & $15(88,5 \%)$ & \multirow{2}{*}{0,085} \\
\hline & Yes/Да & $9(37,5 \%)$ & $2(11,8 \%)$ & \\
\hline \multirow{4}{*}{$\begin{array}{l}\text { Surgical treatment/ } \\
\text { Хирургическое } \\
\text { лечение }\end{array}$} & $\mathrm{No} / \mathrm{HeT}$ & $6(25,0 \%)$ & $2(11,8 \%)$ & \\
\hline & WLE & $15(62,5 \%)$ & $14(82,3 \%)$ & \multirow{3}{*}{0,52} \\
\hline & WLE \& LND/WLE и лимфодиссекция & $2(8,4 \%)$ & $1(5,9 \%)$ & \\
\hline & АКА/Ампутация выше колена & $1(4,1 \%)$ & - & \\
\hline \multirow{2}{*}{$\begin{array}{c}\text { Adjuvant therapy/ } \\
\text { Адъювантная терапия }\end{array}$} & $\mathrm{No} / \mathrm{HeT}$ & $7(30,4 \%)$ & $4(21,7 \%)$ & \multirow{2}{*}{1} \\
\hline & Yes/Да & $16(69,6 \%)$ & $11(73,3 \%)$ & \\
\hline \multirow{6}{*}{$\begin{array}{c}\text { Postoperative } \\
\text { complications/ } \\
\text { Послеоперационные } \\
\text { осложнения }\end{array}$} & $\mathrm{No} / \mathrm{HeT}$ & $5(31,3 \%)$ & $10(76,9 \%)$ & \multirow{2}{*}{0,025} \\
\hline & Yes/Да & $11(68,7 \%)$ & $3(23,1 \%)$ & \\
\hline & Seroma/Серома & $3(27,3 \%)$ & $2(66,7 \%)$ & \multirow{4}{*}{0,62} \\
\hline & Bleeding/ Кровотечение & $1(9,1 \%)$ & - & \\
\hline & Wound dehiscence/Расхождение раны & $6(54,5 \%)$ & $1(33,3 \%)$ & \\
\hline & Infection/Инфекция & $1(9,1 \%)$ & - & \\
\hline \multirow{4}{*}{$\begin{array}{l}\text { Clavein-Dindo score of } \\
\text { complications/ } \\
\text { Степень тяжести по } \\
\text { Clavein-Dindo }\end{array}$} & I & 1 & - & \multirow{4}{*}{0,77} \\
\hline & II & 4 & 2 & \\
\hline & III & 5 & 1 & \\
\hline & IV & 1 & 1 & \\
\hline \multirow{2}{*}{$\begin{array}{l}\text { Recurrence/ } \\
\text { Рецидив }\end{array}$} & $\mathrm{No} / \mathrm{HeT}$ & $14(87,5 \%)$ & $14(93,3 \%)$ & 1 \\
\hline & Yes/Да & $2(12,5 \%)$ & $1(6,7 \%)$ & 1 \\
\hline Overall survival/Общая & выживаемость & NA & NA & 0,16 \\
\hline Disease free surv & ival mean/Безрецидивная выживаемость & 18,6 months/mec & 37,1 months/mec & 0,096 \\
\hline
\end{tabular}

of STS is preferably carried out on a multidisciplinary basis in specialized centers $[7,8]$.

Nearly, 40-60 \% of STS occur in the extremities. $80 \%$ of extremity STS occur in the lower limb. The most common pathological subtypes are undifferentiated pleomorphic sarcoma, leiomyosarcoma, liposarcoma, angiosarcoma, epithelioid sarcoma, and synovial 
Management of extremity STS is built on MDT decision. The cornerstone for management in nonmetastatic cases is a wide-margin oncologic resection that preserves the limb function. Amputation is reserved for non-candidates for limb-sparing surgery after neoadjuvant therapy or for local recurrent selected cases. Preoperative or postoperative radiation is recommended in stages II, IIIA \& IIIB. Neoadjuvant and adjuvant chemotherapy is not the standard of care, but it can be considered in selected cases. Isolated limb perfusion/infusion may have a role in locally advanced non-metastatic tumors [7-10, 12-15]. Upfront surgery with wide margins following a limb preserving strategy was the most common intervention performed in our patients' group.

Extremity soft tissue sarcoma usually presents as a painless mass with a slow rate of growth. The gradual size progression is the single most important warning sign. Large size more than 5 centimeters, pain, being deep to the deep fascia, and recurrence after resection are important alarms as well $[9,16]$. In our research, we hypothesized that obesity may hinder palpation of the mass and may delay the discovery of deep masses leading to the presentation of the disease at a more advanced stage the body fat deposition may mask the discovery of the swelling [11].

Obesity is a major health problem with increasing incidence worldwide. It affects -along with overweightmore than one-third of the world population. Obesity is considered the second leading cause of preventable death in the United States after cigarette smoking. This increasing incidence led to considering obesity as an "epidemic" disease which led to many health and economic challenges. Obesity increases the risk of chronic disease incidence and morbidities such as diabetes mellitus, depression, cardiovascular diseases, shortened life expectancy, and mortality. It is linked also to increased incidence of some cancers as well as cancer-related complications. Body mass index (BMI) is used as an acceptable index to define obesity which starts from a BMI of more than 30 [17-21]. In our locality, the prevalence of obesity reaches up to $46 \%$ in females and $22 \%$ in males [22].

The thigh is considered one of the body fat stores which include the abdominal and the subscapular areas as well [6]. We supposed that being a fat store, the fat deposition in the thigh may hinder the discovery of small-sized soft tissue masses leading to a delayed discovery of soft tissue sarcoma. That was clear as regards the size of tumors at the initial discovery in obese versus non-obese patients. Obese patients

ЛИТЕРАТУРA/REFERENCES

1. Hasley I., Gao Y., Blevins A.E., Miller B.J. The Significance of a «Close» Margin in Extremity Sarcoma: A Systematic Review. Iowa Orthop J. 2018; 38: 123-30.

2. Jacobs A.J., Michels R., Stein J., Levin A.S. Improvement in Overall Survival from Extremity Soft Tissue Sarcoma over Twenty Years. Sarcoma. 2015; 2015: 279601. doi: 10.1155/2015/279601.

3. Atean I., Pointreau Y., Rosset P., Garaud P., De-Pinieux G., Calais G. Prognostic factors of extremity soft tissue sarcoma in adults. A single institutional analysis. Cancer/Radiothérapie. 2012; 16(8): 661-6. present with larger-sized tumors and a higher T stage. Also, the larger diameter of liposarcoma tumours VS. non-liposarcomatous tumours can share in explanation of the greater size of the tumors in the obese group being more of the lipocyte originating sarcoma type.

Obesity has been related to poorer outcomes in patients with extremity soft tissue sarcoma as STS in obese patients is associated with larger tumor sizes, increased surgical complexity, and complications [10]. It has been reported to increase the incidence of STS as well $[23,24]$. Despite the effect on incidence, Alamanda and his colleagues reported that there was no negative impact on survival for obese patients with extremity soft tissue sarcoma [5]. The same results were confirmed by Houdek et al. and Montgomery et al., who reported that obesity does not have a negative impact on functional and oncological outcomes, but they reported an increased incidence of postoperative infection and wound complications in morbidly obese patients necessitating re-admission to the operative theater with the possibility of increased perioperative morbidity and even mortality [11, 24]. In our study, obesity did not affect overall survival or disease-free survival. Yet, obese patients tend to have shorter disease-free survival and coping with published literature - a higher incidence of postoperative complications.

Our study has limitations; being retrospective, the relatively low number of patients, the non-uniform treatment protocols over the years, and the absence of the measurement of thigh circumference.

\section{Conclusion}

Obese patients with thigh soft tissue sarcoma present with larger-sized tumors, a significantly higher T stage, a tendency for isolated lung metastasis, and a higher rate of perioperative complications. Overall survival and disease-free survival are not affected by BMI, although obese patients tend to have shorter disease-free survival.

\section{Ethical approval \& consent to participate}

All procedures performed in the study were following the ethical standards of the institutional research committee and with the 1964 Helsinki declaration and its later amendments. This is a retrospective study for which a specific ethical committee approval is not needed.

Availability of data and materials

All the clinical, radiological \& pathological data used in this manuscript is available on our University database medical system.

4. Park J.H., Kang C.H., Kim C.H., Chae I.J., Park J.H. Highly malignant soft tissue sarcoma of the extremity with a delayed diagnosis. World J Surg Oncol. 2010; 8: 84. doi: 10.1186/1477-7819-8-84.

5. Alamanda V.K., Moore D.C., Song Y., Schwartz H.S., Holt G.E. Obesity does not affect survival outcomes in extremity soft tissue sarcoma. Clin Orthop Relat Res. 2014; 472(9): 2799-806. doi: 10.1007/ s11999-014-3714-7.

6. Karastergiou K., Smith S.R., Greenberg A.S., Fried S.K. Sex differences in human adipose tissues - the biology of pear shape. Biol Sex Differ. 2012; 3(1): 13. doi: 10.1186/2042-6410-3-13. 
7. Gamboa A.C., Gronchi A., Cardona K. Soft-tissue sarcoma in adults: An update on the current state of histiotype-specific management in an era of personalized medicine. CA Cancer J Clin. 2020; 70(3): 200-29. doi: 10.3322/caac. 21605

8. Casali P.G., Abecassis N., Aro H.T., Bauer S., Biagini R., BielackS., Bonvalot S., Boukovinas I., Bovee J.V.M.G., Brodowicz T., Broto J.M., Buonadonna A., De Álava E., Dei Tos A.P., Del Muro X.G., Dileo P., Eriksson M., Fedenko A., Ferraresi V., Ferrari A., Ferrari S., Frezza A.M., Gasperoni S., Gelderblom H., Gil T., Grignani G., Gronchi A., Haas R.L., Hassan B., Hohenberger P., Issels R., Joensuu H., Jones R.L., Judson I., Jutte P., Kaal S., Kasper B., Kopeckova K., Krákorová D.A., Le Cesne A., Lugowska I., Merimsky O., Montemurro M., Pantaleo M.A., Piana R., Picci P., Piperno-Neumann S., Pousa A.L., Reichardt P., Robinson M.H., Rutkowski P., Safwat A.A., Schöffski P., Sleijfer S., Stacchiotti S., Sundby Hall K., Unk M., Van Coevorden F, van der Graaf W.T.A., Whelan J., Wardelmann E., Zaikova O., Blay J.Y.; ESMO Guidelines Committee and EURACAN. Soft tissue and visceral sarcomas: ESMO-EURACAN Clinical Practice Guidelines for diagnosis, treatment and follow-up. Ann Oncol. 2018; 29. doi: 10.1093/annonc/mdy096.

9. Puri A., Gulia A. Management of extremity soft tissue sarcomas. Indian J Orthop. 2011; 45(4): 301-6. doi: 10.4103/0019-5413.82332.

10.Brinkmann E.J., Ahmed S.K., Houdek M.T. Extremity Soft Tissue Sarcoma: Role of Local Control. Curr Treat Options Oncol. 2020; 21(2): 13. https://doi.org/10.1007/s11864-020-0703-9.

11.Montgomery C., Harris J., Siegel E., Suva L., Wilson M., Morell S., Nicholas $R$. Obesity is associated with larger soft-tissue sarcomas, more surgical complications, and more complex wound closures (obesity leads to larger soft-tissue sarcomas). J Surg Oncol. 2018; 118(1): 184-91. doi: $10.1002 /$ jso. 25119 .

12.Stevenson M.G., Musters A.H., Geertzen J.H.B., van Leeuwen B.L., Hoekstra H.J., Been L.B. Amputations for extremity soft tissue sarcoma in an era of limb salvage treatment: Local control and survival. J Surg Oncol. 2018; 117(3): 434-42. doi: 10.1002/jso.24881.

13.Byerly S., Chopra S., Nassif N.A., Chen P., Sener S.F., Eisenberg B.L., Tseng $W . W$. The role of margins in extremity soft tissue sarcoma. J Surg Oncol. 2016; 113(3): 333-8. doi: 10.1002/jso.24112.

14.Al-Refaie W.B., Habermann E.B., Jensen E.H., Tuttle T.M., Pisters P.W., Virnig B.A. Surgery alone is adequate treatment for early stage soft tissue sarcoma of the extremity. Br J Surg. 2010; 97(5): 707-13. doi: 10.1002/bjs.6946.

15.Endo M., Lin P.P. Surgical margins in the management of extremity soft tissue sarcoma. Chin Clin Oncol. 2018; 7(4): 37. doi: 10.21037/ cco.2018.08.10.

16.Umer H.M., Umer M., Qadir I., Abbasi N., Masood N. Impact of unplanned excision on prognosis of patients with extremity soft tissue sarcoma. Sarcoma. 2013. doi: 10.1155/2013/498604.

17.Hales C.M., Carroll M.D., Fryar C.D., Ogden C.L. Prevalence of Obesity and Severe Obesity Among Adults: United States, 2017-2018. 2020; (360): 1-8.

18.Wang Y., Beydoun M.A., Min J., Xue H., Kaminsky L.A., Cheskin L.J. Has the prevalence of overweight, obesity and central obesity levelled off in the United States? Trends, patterns, disparities, and future projections for the obesity epidemic. Int J Epidemiol. 2020; 49 (3): 810-23. doi: 10.1093/ije/dyz273.

19.Wolin K.Y., Carson K., Colditz G.A. Obesity and cancer. Oncologist. 2010; 15(6): 556-65. doi: 10.1634/theoncologist.2009-0285.

20.Nguyen D.M., El-Serag H.B. The epidemiology of obesity. Gastroenterol Clin North Am. 2010; 39(1): 1-7. doi: 10.1016/j. gtc.2009.12.014.

21.Hruby A., Hu F.B. The Epidemiology of Obesity: A Big Picture. Pharmacoeconomics. 2015; 33(7): 673-89. doi: 10.1007/s40273-0140243-x.

22.Alebshehy R., Shuaib N.M., Mbako J.D., Barffo D., Nuotol R.K. Determinant Analysis of Obesity among Adult Females in Egypt. Egypt J Hosp Med. 2016; 65(1): 662-9. doi: 10.12816/0033779.

23.Tavani A., Soler M., La Vechia C., Negri E., Gallus S., Franceschi $S$. Body weight and risk of soft-tissue sarcoma. Br J Cancer. 1999; 81(5): 890-2. doi: 10.1038/sj.bjc.6690781.

24.Houdek M.T., Hevesi M., Griffin A.M., Wunder J.S., Ferguson P.C. Morbid Obesity Is Associated With an Increased Risk of Wound Complications and Infection After Lower Extremity Soft-tissue Sarcoma Resection. J Am Acad Orthop Surg. 2019; 27(21): 807-15. doi: 10.5435/ JAAOS-D-18-00536.

Поступила/Received 06.08.2021 Принята в печать/Accepted 04.10.2021

\title{
ABOUT THE AUTHORS
}

Omar Hamdy, MD, Lecturer, Surgical Oncology Unit, Oncology Center Mansoura University (OCMU) (Mansoura, Egypt). Researcher ID (WOS): W-8287-2019. Author ID (Scopus): 57200278486. ORCID: 0000-0002-2924-4207.

Khalid Atallah, MSc, Assistant Lecturer, Surgical Oncology Onit, Oncology Center Mansoura University (OCMU) (Mansoura, Egypt). Author ID (Scopus): 57208687994. ORCID: 0000-0001-6503-4867.

Mohamed H. Ros, MB BCh, Medical Intern, Mansoura University Hospitals (Mansoura, Egypt). Author ID (Scopus): 57208507986. ORCID: 0000-0002-7150-9424.

Islam H. Metwally, MD, MRCS, Lecturer, Surgical Oncology Onit, Oncology Oenter Mansoura University (OCMU) (Mansoura, Egypt). Author ID (Scopus): 57142135100. ORCID: 0000-0002-5981-9614.

\section{AUTHOR CONTRIBUTION}

Omar Hamdy: conceived the study, analyzed the data, and wrote the manuscript.

Khalid Atallah: collected the data and approved the manuscript.

Mohamed H. Ros: collected the data and approved the manuscript.

Islam H. Metwally: reviewed the statistics, and all authors discussed the manuscript.

\author{
Funding \\ This study required no funding \\ Conflict of interests \\ The authors declare that they have no conflict of interest.
}

\section{СВЕДЕНИЯ ОБ АВТОРАХ}

Омар Хамди, MD, преподаватель, Отделение хирургической онкологии, онкологический центр Университета Мансуры (Мансура, Египет). Researcher ID (WOS): W-8287-2019. Author ID (Scopus): 57200278486. ORCID: 0000-0002-2924-4207.

Халид Аталла, MSc, преподаватель, Отделение хирургической онкологии, онкологический центр Университета Мансуры (Мансура, Египет). Author ID (Scopus): 57208687994. ORCID: 0000-0001-6503-4867.

Мохамед Х. Рос, MB BCh, медицинский стажер, Университетские больницы Мансуры (Мансура, Египет). Author ID (Scopus): 57208507986. ORCID: 0000-0002-7150-9424. 
Ислам Х. Метвалли, MD, MRCS, член Королевской коллегии хирургов, Отделение хирургической онкологии, онкологический центр Университета Мансуры (Мансура, Египет). Author ID (Scopus): 57142135100. ORCID: 0000-0002-5981-9614.

\section{ВКЛАД АВТОРОВ}

Омар Хамди: разработка концепции научной работы, сбор и обработка данных, статистическая обработка, составление черновика рукописи.

Халид Аталла: анализ научной работы, критический пересмотр с внесением ценного интеллектуального содержания. Мохамед X. Рос: анализ научной работы, критический пересмотр с внесением ценного интеллектуального содержания. Ислам Х. Метвалли: анализ полученных результатов, статистическая обработка.

\section{Финансирование}

Это исследование не потребовало дополнительного финансирования.

\section{Конфликт интересов}

Авторы заявляют об отсутствии конфликта интересов. 